\title{
Brazilian Unified Health System and democracy: nursing in the context of crisis
}

\author{
Sistema Único de Saúde e democracia: a enfermagem no contexto de crise \\ Sistema Único de Salud y democracia: la enfermería en el contexto de crisis
}

\section{Janieiry Lima de Araújo', Rodrigo Jácob Moreira de Freitas', Maria Vilani Cavalcanti Guedes', Maria Célia de Freitas', Ana Ruth Macedo Monteiro', Lucilane Maria Sales da Silva'}

'Universidade Estadual do Ceará. Fortaleza, Ceará, Brazil.

\section{How to cite this article:}

Araújo JL, Freitas RJM, Guedes MVC, Freitas MC, Monteiro ARM, Silva LMS. Brazilian Unified Health System and democracy: nursing in the context of crisis. Rev Bras Enferm [Internet]. 2018;71(4):2066-71.

DOI: http://dx.doi.org/10.1590/0034-7167-2017-0352

\section{Submission: 05-21-2017 Approval: 08-23-2017}

\section{ABSTRACT}

Objective: to discuss, taking for reference the crisis in Brazil and its impact on public health policies, the insertion of Brazilian nursing in that context and its ways of practicing the profession, based on the study about the politicality of care. Method: the reflection is divided into two topics, the first is about public policies, the Brazilian Unified Health System and the deconstruction of the right to health with neoliberal offensive; and the second is about the nursing political action in the fight for the right to health and for democracy. Final considerations: we emphasize that nursing must assume its sociopolitical role to contribute to the construction of a better and fairer Brazil, saying no to neoliberal reforms, as well as fighting for rights already acquired and for the resumption of the democratic stability in the country.

Descriptors: Health Policy; Democracy; Integral Health Assistance; Reform of the Health Services; Nursing.

\section{RESUMO}

Objetivo: discutir, tomando por referência a crise no Brasil e sua repercussão nas políticas públicas de saúde atuais, a inserção da enfermagem brasileira nesse contexto e seus modos de agir para realização do cuidado. Método: reflexão ancorada nos estudos sobre a politicidade do cuidado. Resultados: está dividida em dois tópicos, o primeiro sobre políticas públicas, Sistema Único de Saúde e a desconstrução do direito à saúde com a ofensiva neoliberal; e o segundo sobre a ação política da enfermagem na luta pelo direito a saúde e pela democracia. Considerações finais: enfatiza-se que a enfermagem deve assumir seu papel político-social de forma a contribuir na construção de um Brasil melhor e mais justo, dizendo não às reformas neoliberais, bem como lutando pela garantia dos direitos já adquiridos e pela retomada da estabilidade democrática ao país.

Descritores: Política de Saúde; Democracia; Assistência Integral à Saúde; Reforma dos Serviços de Saúde; Enfermagem.

\section{RESUMEN}

Objetivo: discutir, tomando por referencia la crisis en Brasil y su repercusión en las políticas públicas de salud actuales, la inserción de la enfermería brasileña en ese contexto y sus modos de actuar para la realización del cuidado, basado en el estudio sobre la politicidad del cuidado. Método: la reflexión se divide en dos temas, el primero en las políticas públicas, el Sistema Único de Salud y la deconstrucción del derecho a la salud con la ofensiva neoliberal; y el segundo sobre la acción política de la enfermería en la lucha por el derecho a la salud y la democracia. Consideraciones finales: se enfatiza que la enfermería debe asumir su papel político-social de forma a contribuir en la construcción de un Brasil mejor y más justo, diciendo no a las reformas neoliberales, así como luchando por la garantía de los derechos ya adquiridos y por la reanudación de la estabilidad democrática al país.

Descriptores: Política de Salud; Democracia; Atención Integral de Salud; Reforma de la Atención de Salud; Enfermería. 


\section{INTRODUCTION}

For 28 years Souza and Gutiérrez ${ }^{(1)}$, in the search for understanding "What nursing is," have presented questions for the criticism and reflection of the class to elucidate how nursing is conceived and practiced. For the researchers, Brazilian nursing was, and still is, influenced by changes in social structure and their impact on the public health policies of the State. Cognizant of this facet, nursing will be able to determine the production of knowledge and values that guide its practice, as well as the role that professionals assume within society.

After almost thirty years since the publication of Souza and Gutierrez $^{(1)}$, Brazilian nursing gradually started answering such questions, both in the theoretical and practical field, by assuming a social role relevant in the development of health policies. Today, nursing corresponds to an important health-related job category, covering $50 \%$ of the 3.5 million workers in the sector.

In Brazil, nursing is composed by $80 \%$ technicians and assistants and $20 \%$ nurses who routinely take care of promotion, prevention, recovery and rehabilitation of the population's health ${ }^{(2)}$.

The profession represents a class of health workers present in all municipalities, with strong insertion in the Brazilian Unified Health System (SUS), and $59.3 \%$ of the teams work in the public sector. In addition, $31.8 \%$ of them work in the private sector, $14.6 \%$ in philanthropy and $8.2 \%$ in teaching activities. Composed of $84.6 \%$ women, nursing is a distinctly female profession.

Data indicate difficulty in finding employment in the field by $65.9 \%$ of professionals, with $10.1 \%$ having indicated unemployment situation in the last twelve months. The private and philanthropic sectors are the ones that underpay their employees the most, not exceeding two thousand Brazilian reais, which is a decisive situation for the existence of more than one employment relationship and bad working conditions. This fact justifies $66 \%$ of interviewed professionals who reported tiredness in the work environment ${ }^{(2)}$.

The current profile of Brazilian nursing reflects, therefore, the historicity of the profession and its inclusion in society and in healthcare. Thus, after analyzing the social context and its transformations, we will be able to determine and understand the diversity of knowledge and the values produced by the discipline, which, consequently, influences the practice ${ }^{(2)}$.

The social role taken over by nursing is aligned with the Brazilian democratic State, as well as principles and guidelines of SUS, public policy responsible for the change in the paradigm of health care after the Constitution of 1988. By idealizing a State policy, new conceptual arrangements on care and health have emerged from the struggle for the democratization of the country and the end of the Military Dictatorship (1964-1984). These ideas arise in intellectual and academic debates and in the daily life of popular movements and of professionals for the defense of health as a right of citizenship ${ }^{(3)}$.

At the time of the SUS structuring, when the Brazilian democracy was reestablished after the military dictatorship, nursing started to explore new scenarios of expertise and responsibilities in the health sector. These scenarios - whether in primary care hospitals, with high technological tools, whether in the research and management of health services, in the training of health workers and, especially, of nurses - determined new responsibilities and requirements of theoretical knowledge to meet the practical demands that begin to emerge ${ }^{(4)}$.

Despite the professional and intellectual advancement of Brazilian nursing, it is urgent to reflect upon the moment of political and economic crisis faced by Brazil, with explicit threats to the neoliberal ideology that aims to dismantle the democratic rule-of-law State, which, through the development of progressive policy in recent decades, searched the effectiveness of SUS as a way to ensure the right to health. Associated with this neoliberal offensive, the manipulative power of the media feeds the popular discrediting regarding institutions and powers, which are contaminated by corruption and mismanagement of public affairs. This portrait invites us to resume the question ${ }^{(1)}$ that guides our reflection: Which processing actions would be needed to improve the nursing conditions in the social structure?

In the search for answers to this question we present this theoretical reflection, whose objective is to discuss, having as a reference the crisis in Brazil and its impact on public health policies, the insertion of Brazilian nursing in this context and its ways of promoting the practice. The theme becomes relevant and current as it allows one to reflect upon the social transformations, seeking to understand the meaning and functioning of global and Brazilian society, as well as to rethink "What is nursing?" (1) in order to build bridges to the future of the health worker in the field of assistance, research, management/administration and education.

\section{PUBLIC POLICY AND THE BRAZILIAN UNIFIED HEALTH SYSTEM (SUS): THE DECONSTRUCTION OF THE RIGHT TO HEALTH AND THE NEOLIBERAL OFFENSIVE}

SUS, understood as an alternative health model of counterhegemonic character in relation to neoliberalism and its mode of production and social reproduction, is the product of the participatory fight of civil society for the democratization of the country and the universal right to health, this fight is recognized historically as the Brazilian Health Reform (RSB). It is a popular achievement, a public policy desired by the society, guaranteed by the Citizen's Constitution and legalized by the Organic Health Laws $(\mathrm{LOS})^{(3)}$.

However, to ensure the effectiveness of SUS as a public policy has never been a simple task. Obstacles and challenges persist along its course. Financing and budget guarantees stood for many years as unknowns for managers and health professionals. Eleven years passed until minimum resources were legally guaranteed for the financing of public health actions and services in the three spheres of the government, through the Constitutional Amendment (CE) no. 29, from September 13, 2000. And it took twice as long for SUS to be regulated by Decree no. 7508 , from June 28, $2011^{(5)}$.

Subsequently, Supplementary Law (LC) no. 141, from January 13,2012 , established the assessment criteria of transfers to health and supervisory standards, assessment and control of health expenditure. Therefore, the device came to discipline the financing and the compliance with the investments in the sector, to modify the limits and rules for health expenditure and officiate the parliamentary amendments required ${ }^{(5)}$. The approval of CE no. 86, from March 17, 2015, which modified the articles 165, 166 and 198 of the Federal Constitution, is associated with this, dealing with the implementation of the budget programming in relation to $\mathrm{SUS}{ }^{(6)}$. 
The implications of CE 86/2015, which stipulated the federal financing not less than $15 \%$ of the Current Net Revenue (RCL), were negative still in 2015, but they were only felt in 2016, when the calculation of the minimum application based on RCL began to be adopted. From that we have the imposing budget model, whose rules will aggravate even more the situation of the SUS underfinancing, which will represent the partial loss of social rights ${ }^{(5-6)}$.

Surely there is a persistent instability and insufficiency of resources imposed by neoliberal offensive in several governments post-1988, which came to derail the implementation of the right to health. The unfair tax structure is associated with this characteristic, as well as the payment of public debt interest, never audited, and the constant changes in legislation as determinants of the SUS underfinancing, which configures a throwback imposed to Social Security ${ }^{(7)}$.

In Brazil, the Democratic Rule-of-Law State ensures the operation and execution of public policies through tax collections. However, existing peculiarities in tax legislation have transformed the country into a haven for the super-rich. Data prove that the tenth more rich of the population owns half of the household income in Brazil (52\%); the hundredth more rich, something near to $(23.2 \%)$; and the thousandth more rich owns almost a tenth of this income $(10.6 \%)$, indices that exceed the limits considered tolerable for democratic societies with a universal healthcare system. This portion of the population, the superrich and rich, pay less tax in proportion to their income than a citizen of the upper middle class, especially the employee. Thus, the poor and the workers, those who are most dependent on SUS, are the responsible for paying more taxes ${ }^{(8)}$.

This characteristic violates the principle of progressive tax whereby the level of taxation should grow with the income. The country does not have a constitutional device that allows the taxation of large fortunes. This happens due to the legal residency of tax exemptions on profits and dividends distributed by companies to their partners and shareholders. The distributive potential of the income tax in Brazil, measured through the Gini Index, is lower than in most developed countries of Latin America, such as Mexico, Uruguay, Argentina and Chile, and well below the European countries ${ }^{(8)}$.

It is noteworthy the worsening economic crisis and the installation of a political crisis since the end of the electoral process in 2014. The scenario becomes complicated in February 2016 with the opening of the process of removal, by the National Congress, of President Dilma Rousseff, elected with more than 54 million votes. The fiscal adjustment and the stagnation of the economic growth, added to the increase in unemployment in the big cities, in the interest rate and in the debt, determined the decline in household consumption. Associated with the financial crisis in several states of the Federation, the prosecution of crimes of fiscal responsibility, but mainly the loss of support from the parliamentary system, combined with a negative marketing provided by mainstream media, under the observing gaze of the judiciary, led to the approval of the impeachment of the President by the Senate ${ }^{(5)}$.

After fourteen years of progressive public policies, the face of the society that shapes itself (post-coup for some, post-impeachment for others) is still unknown. We live in times of uncertainty as to the rights of citizenship and maintenance of democracy. With the end of the second term of Rousseff, who has not had her political rights suspended, but was held responsible for the crime of fiscal responsibility, the so-called "pedaladas" - Portuguese for pedalling -, the then Vice President Michel Temer assumes the Presidency of the country. In his opening speech, he evokes hope and resumption of confidence in Brazil. For Temer, the moment of uncertainty comes to an end. Now is time to unite the country and put national interests above the interests of certain groups. He points out as foundations of his government the administrative efficiency, growth, job creation, legal security, expansion of social programs and the pacification of the country ${ }^{(5)}$.

The package of reforms proposed by Temer's government has broad parliamentary support. However, the force with which the texts are considered in the legislative houses makes us question whether the debate of affairs was sufficiently discussed to be approved with astonishing rapidity and, especially, if the measures hurt the constitutional rights ${ }^{(5-6)}$. Among the key reforms, the discussion on public expenditure proved to be urgent, starting the debate during the provisional government. Already President, in December 2016, despite the dissatisfaction and distrust of the population, Temer sanctions the CE no. 95, which deals with the new Fiscal Regime that limits public expenditure for twenty years ${ }^{(5)}$.

On the new fiscal regime, which begins in 2018, expenditures will not be higher than the inflation; there will be individual limits for the three powers, extending to the Public Prosecutor's Office and the Public Defender's Office; the intergovernmental transfers become exempt, such as for the Fund for the Maintenance and Development of Basic Education (Fundeb), and unexpected or eventual expenses. According to the Federal Government, as of 2018 actions will be implemented to protect these sectors, which will ensure no punishment or interruption of social programs. The intention is to implement automatic measures of expenditure control in case of non-compliance. This measure aims to resume economic growth, political and social stability to reverse the crisis. The argument presented lies in two aspects that hinder the resumption of the country's growth and perpetuate the economic crisis and the recession inherited: the abandonment of fiscal prudence and selective tax exemptions ${ }^{(5,8)}$.

The reforms follow their own course, and in July 2017, amid protests in the streets and accusations/coercive measures/arrests of people connected to the government, the Labor Reform is approved by the Congress, by the Federal Senate, and subsequently sanctioned by the Executive. Thus, the Consolidation of Labor Laws (CLT), after seventy years of existence, suffers significant changes ${ }^{(5)}$.

For class entities, unions, intellectuals, experts and various social and religious institutions, the labor reform is a usurpation of the constitutional rights. The employers' interests overlapped on workers' rights, who will feel, in the near future, the impacts on their life and health. It is alleged that CLT was not reformed but ripped to shreds. Combined with the approval of the Outsourcing Law, which regulates and extends the possibility of hiring for the main activities of the company, the loss of social and labor rights will make Brazil go backwards in the world of work ${ }^{(5)}$.

Despite the argumentative power of the government, expenditure on advertising and the time spent by the mainstream media to explain/ convince the population about the necessity of these reforms (tax, labor and social security) along the lines proposed; various organs 
and institutions, unions and council from various fields, universities and their staff associations, research associations and professional categories, social movements and popular advice do not look at them from the same perspective. For such representatives and members, to freeze public expenditure for twenty years with the sole purpose of paying the national debt will harm health, education, public services and servers. Furthermore, workers' rights are usurped with the labor reform, social security will be impaired with the welfare reform, as the new fiscal regime and other reforms will take the social rights conquered from the poor. Brazil lives, therefore, the greatest neoliberal offensive aiming to dismantle the Democratic Rule-of-Law State, a threat to democracy and citizenship ${ }^{(7)}$.

Regarding RBS and the protection of SUS, Paim ${ }^{(7)}$ exposes the existence of asymmetric forces in the field of political and ideological discourse in this new social scenario. In favor, there are technicians, researchers, health workers and intellectuals linked to the Brazilian Center for Health Studies (Cebes), to the Brazilian Association of Collective Health (Abrasco), to the Brazilian Health Economics Association (ABrES), among other entities, social movements and segments from left-wing parties, mainly ${ }^{(7)}$. Against, there is the power of the health business community linked to the financial capital, particularly operators of health plans and the industrial capital; the mainstream media and advertising; medical corporations; political oligarchies, in addition to right-wing parties. Certainly, a dismount of SUS is under way, threatening the universality of the right to health, which determines the need of health professionals, public administrators of SUS, health advisors and society to position themselves for the uncompromising defense of the right to health and democracy ${ }^{(7)}$.

SUS, to many intellectuals, during its implementation was constituted as a way to reduce inequalities, deploy social justice and citizenship, tolerance and respect for human rights. Through a policy of universal health care, the construction of a fairer, more human and more caring new society was sought. Almost thirty years later, society finds itself immersed in an ideological and political war that directly affects the life in society and its ethical-moral principles ${ }^{(6)}$.

A new social pact is urgent to put the Brazilian democracy back on the track of citizenship ${ }^{(6)}$. Naively, the population stands in the middle of disinformation, media manipulation, not knowing exactly where this "crisis" will take them. The general elections for President, governors, senators, federal and state deputies in 2018 are a possibility to start over. Despite all social incredulity with the current political class, whose representativeness "on behalf of the people" vanishes with constant corruption scandals, is by exercising citizenship and political actions that democracy will be resumed.

\section{NURSING POLICY ACTION IN THE FIGHT FOR THE RIGHT TO HEALTH AND DEMOCRACY}

Historically, nursing built its expertise at the level of hospital healthcare services, following a logic of the biomedical model and the technical division of labor in health and nursing. After SUS, other practice scenarios emerged as a field in which the nurse could exercise his/her social practice. The Participation Movement was important for the construction of knowledge in nursing, because, by assuming the Brazilian Nursing Association (ABEn), it reflected upon the technical-scientific development in addition to the political and social projection of the profession, renovating university curricula and discussing new directions for the appreciation of nursing within health care teams ${ }^{(9)}$.

To better discuss the political action of nursing, urgent and necessary, we revisit the studies ${ }^{(10)}$ who put the "politicality of care" as an alternative to legitimize the practice by sharing the powers in the spaces of society. This action concerns the development of the subjects' autonomy by reducing asymmetries of the existing power in care, which is possible by the trihedron: knowing to take a better care, taking care to confront, and taking care to emancipate. In this sense, one must seek the appreciation of the profession in order to rescue what it has to contribute to health and democracy when taking care of individuals, family and/or community members.

Nursing, having care as core competence and responsibility, expresses power to get in different fields of knowledge, focusing on the person to whom the care will be provided. It is possible to establish more intensive dialogue channels with other disciplines and, interdisciplinary, to seek technologies necessary to the assistance, establishing relationships with the team and with the family and acting in the process of reality transformation $^{(10)}$. The diversity of practical scenarios allows nurses an active participation in health care, particularly by increasing their performance in management/administration of services.

By contrast, it has been observed little political action of these professionals in the health reform process and in the fight for democracy. Therefore, nursing needs to learn its context in a formal and political way, in an approximate movement of a concrete reality and always more complex in order to better intervene and take care, in a propulsion of new ordinations of power ${ }^{(10)}$.

Nurses must think critically about their own practice, recognizing themselves as subjects and thus promoting the democratization of society through their political participation. Depending on the consistency of their positioning, there is greater or lesser possibility their participation will contribute to the construction of public health policies that contemplate the principles of $S U S^{(4)}$.

This construction of the right to health and democracy, conflicts and uncertainties may emerge, translated into a subversive political and revolutionary action. Nursing must understand that its action may trigger a change in social relations, so the care can be emancipating, focusing on the autonomy of the subjects. The conception of emancipating care presupposes the understanding that solidarity and interdisciplinary actions are ways to reorder, progressively, power asymmetries and rework the help-power management ${ }^{(10)}$.

Thus, the proposed trihedron ${ }^{(10)}$ would be implemented: through the articulation of the socio-historical context in which those practices are produced with "knowing to take a better care"; through the correlation of forces and disputes between social production with "caring to confront"; and, finally, with the interpretation and reinterpretation of symbolic forms, which operate dynamic movements, enhancing the "taking care to emancipate."

With this, nursing is called to assume its political and social role in order to contribute to health, citizenship and democracy. Also, it is noteworthy the social role of universities, which instigate the training of nurses committed to the political reality, 
agent of the transformation of society. It is through a training process committed to the social context of the country that the nursing care, beyond its technical and biological dimension, could be a key element in changing the crisis situation of the country, being the nurse the subject that allows the emancipating care through his/her actions ${ }^{(10)}$.

In this scenario, it is important for nursing to surpass the theoretical challenge ${ }^{(4,6)}$ required for the construction of science itself, triggering benchmarks that build a new transforming know-how for the practice in the various spaces of insertion of the nursing worker, whether in individualized care, or related to groups, family and community members. In addition, as an important part of the health work, it is necessary to align the set of entities with the defense of SUS.

It is necessary to highlight, about the current social context, that the representative entities of nursing - namely, Brazilian Nursing Association (ABEn), the National Confederation of Health Workers (CNTS), Nursing Federal Council (COFEn), National Federation of Nurses (FNE), National Confederation of Social Security Workers (CNTSS) and National Association of Nursing Assistants and Technicians (Anaten) - have positioned themselves against the disassemble of SUS and in defense of health as a constitutional right. Together, they strongly repudiate the project of deconstruction of SUS and the threats to link health policies to the market. For nursing, health is an inalienable right of the individual, a right to citizenship guaranteed by the Constitution of 1988. It is the role of nursing professionals to defend this right, placing it as a priority in the development of State policies. Thus, the fight against the privatization of health and the reduction of rights is a fight of the nursing field. There is an urgent need to reflect upon the relevance of its historic participation in the construction and maintenance of a universal health care system, to face the challenges of the present and launch itself into the future, even if uncertain ${ }^{(9)}$.

The overcoming of the political challenge will allow the construction of a critical conscience to spread among the people, being a tool for changes in the Legislative Power, which is essential to advance in national projects. Nursing should act on the restructuring of procedures that ensure effective democratic representation of society in the Legislative and Executive powers, with effective transparency in the control of its actions, and fight to expand the financing, to improve the management and strengthen the social participation of $\mathrm{SUS}^{(6)}$.
As a possible horizon in this hopeless scenario, the necessary changes will only occur through the activism of thousands of workers, managers and health advisers, academics (lecturers, students and researchers), as well as society in general, forming "islands" or "niches" of resistance. The islands of possible advancements and resistance to the dismantling should be taken as irreplaceable threshold for future resumption of the (re)construction of SUS, considering the $\operatorname{crisis}^{(6)}$. For now, we must say no to neoliberal reforms (tax, labor and social security), and fight for the rights of citizenship acquired by Brazilian people's historical struggle. To resist and occupy important political spaces are the directions toward the resumption of democratic stability in the country.

\section{FINAL CONSIDERATIONS}

Despite the progress observed in the last thirty years, the current social situation reveals a difficult reality for the insertion of the nurse as a worker of SUS, considering the frequent attacks on the Constitution of 1988 and therefore the right to health in Brazil. The deterioration and the disqualification of public health services, the precarious work in the sector, under the strong influence of a neoliberal model that drives the professional to the dictates of market logic, are some points that need to be (re) designed so there is a transformation in nursing in a near future.

This challenge presents itself to the nursing training, either at undergraduate or graduate level. The courses still form professionals with a fragmented vision, based on the biomedical model, with difficulties in multidisciplinary teamwork and in the integration of interdisciplinary knowledge, little committed to public health policies and unaware of SUS and of the social reality.

Nursing should be understood as part of a social structure and, as such, plays roles that enable changes in health policies, which should become actions geared toward citizenship, aiming to the promotion of the human health and reduction of social inequities. We need to build a critical knowledge regarding the political, social, economic and cultural aspects of the Brazilian society.

This way, the improvement of nursing will happen along with the transformation of the existing social reality, and the social changes can contribute to positive transformations in nursing, regarding the resumption of the Democratic Rule-of-Law State, in building a more humane and fairer society, balancing technological advancement and social health demands, overcoming the scary political-economic model that is ahead.

\section{REFERENCES}

1. Souza MF, Gutierrez MG. Em que consiste a enfermagem. Acta Paul Enf. 1989;2(1):5-8.

2. Silva MCN, Machado MH, (Orgs). Perfil da enfermagem no Brasil [Internet]. 2015 [cited 2016 Oct 15]. Available from: http://www. cofen.gov.br/perfilenfermagem/

3. Conh A, Nunes E, Jacobi PR, Karsch US. A Saúde como direito e como serviço. 7ª ed. São Paulo: Cortez, 2015.

4. Melo CMM, Santos TA. A participação política de enfermeiras na gestão do Sistema Único de Saúde em nível municipal. Texto Contexto Enferm [Internet]. 2007 [cited 2016 Oct 15];16(3):426-32. Available from: http://www.scielo.br/pdf/tce/v16n3/a07v16n3.pdf

5. Centro Brasileiro de Estudos de Saúde-CEBES. Democracia, crise política e saúde. Rev Saúde Debate[Internet]. 2016[cited 2017 Jul 20];40(Esp). 250p. Available from: http://40anos.cebes.org.br/democracia-crise-politica-e-saude/ 
6. Centro Brasileiro de Estudos de Saúde-CEBES. Saúde em debate. Rev Saúde Debate [Internet]. 2017[cited 2017 Jul 20];41(113). 346p. Available from: http://cebes.org.br/publicacao/revista-saude-em-debate-vol-41-ed-113/

7. Paim JS. Seguridade Social, financiamento e crise do Sistema Único de Saúde-SUS. Plataforma Política Social[Internet]. $2016[$ cited 2017 Jan 15]. Ano 5. Available from: http://plataformapoliticasocial.com.br/seguridadesocialfinanciamentoecrisedosistemaunicodesaudesus/

8. Gobetti SW, Orair RC. Sistema tributário brasileiro: o paraíso dos superricos [Internet]. 2016 [cited 2017 Jan 12]. Available from: https://nacoesunidas.org/brasil-e-paraiso-tributario-para-super-ricos-diz-estudo-de-centro-da-onu/

9. Associação Brasileira de Enfermagem-ABEn. Enfermagem em defesa da saúde como direito constitucional [Internet]. 2016 [cited 2017 Jan 12]. Available from: http://www.cofen.gov.br/enfermagem-em-defesa-da-saude-como-direito-constitucional_43418.html

10. Pires MRGM. Pela reconstrução dos mitos da enfermagem a partir da qualidade emancipatória do cuidado. Rev Esc Enferm USP[Internet]. 2007 [cited 2016 Oct 15];41(4):717-23. Available from: http://www.scielo.br/pdf/reeusp/v41n4/24.pdf 